\title{
KEY FACTORS FOR A CONTINUOUS IMPROVEMENT PROCESS
}

\author{
Hector Ricardo Formento \\ National University of General Sarmiento, Argentina \\ E-mail: hformen@ungs.edu.ar
}

Franco Javier Chiodi

National University of General Sarmiento, Argentina

E-mail: fchiodi@ungs.edu.ar

Fernando Juan Cusolito

National University of General Sarmiento, Argentina

E-mail: fcusolit@ungs.edu.ar

Lucas Ariel Altube

National University of General Sarmiento, Argentina

E-mail: laltube@ungs.edu.ar

Sebastian Pablo Gatti

National University of General Sarmiento, Argentina

E-mail: sgatti@ungs.edu.ar

Submission: $27 / 04 / 2013$

Revisions: 09/06/2013

ABSTRACT

Accept: 24/06/2013

The goal of this work was to examine the content of continuous improvement processes, taking into account its inclusion in modern organizations' strategies. Continuous improvement plays an important role in ISO 9000 norms and excellence models.

This paper argues that several specific issues must be taken into account in order to reach successful outcomes.

This work starts with a literature review on the matter. On this basis we designed a survey of a group of 30 large companies, selected according to their billing, its market share, its membership to quality institutions and the existence of a certified management system.

Finally, we compared the development of continuous improvement process in companies with very effective results and with scarce results. Differences that emerged from this comparison enabled us to identify critical factors for achieving a successful improvement process. 
DOI: 10.14807/ijmp.v4i2.76

As there are no recent researches on continuous improvement programs in Argentina, this paper contributes to recognizing and systematizing what has been done, comparing it with theoretical framework and uncovering research gaps for future studies. However, further research must confirm these findings and move forward on the analysis of intangible factors, like: internal communications, climate, culture, self reflexion, consensus, etc.

Keywords: Continuous improvement; key factors; management; team work

\section{INTRODUCTION}

In the approach proposed by Imai (1986), the kaizen or continuous improvement implies a shift in the Taylorist paradigm of labor division. That means, to generate a dual function of work, shared between routine and improvement. That is, everyone in the organization will use a portion of their time to solve problems or develop opportunities for improvement. This will be made applying their experience through a scientific method of diagnosis. This idea is so simple to understand but complex to implement in daily practice.

Some surveys confirm this perception. A study of U.S. firms showed that while $70 \%$ of the plants had implemented techniques "Lean manufacturing", $74 \%$ of them were dissatisfied with the results achieved (PAY, quoted in ANAND; WARD; TATIKONDA; SHILLING, 2009).

Another study showed that only $11 \%$ of companies considered their continuous improvement initiatives had been successful (MENDELBAUM, quoted in ANAND et al., 2009).

Multiple studies have analyzed the continuous improvement processes in companies and organizations of different types. Using a simplified classification, the main approaches are: the analysis of core competencies, barriers and facilitators (MESQUITA; ALLIPRANDINI, 2003; MARIN GARCIA; PARDO DEL VAL; BONAVIA MARTIN, 2008; ALBORS GARRIGOS; HERVAS OLIVER; SEGARRA OÑA, 2009; GARCIA SABATER; MARIN GARCIA, 2009), models (BESSANT; CAFFYN; GALLAGER, 2001; WU; CHEN, 2006), knowledge and learning process (BUCKLER, 1996; MURRAY; CHAPMAN, 2003; DAVISON; GORDON; ROBINSON, 2005; SAVOLAINEN; HAIKONEN, 2007; JABROUNI; KAMSU-FOGUEN; GENESTE; VAYSSE, 2011), quantitative studies of programs in different sectors and countries 
(TERSIOVSKI; SOHAL, 2000; SCOTT; WILCOCK; KANETKAR, 2009) the relationship of continuous improvement with change management and TQM (CHOI, 1995; JUNG; WANG, 2006), and history and evolution of continuous improvement (BHUIYAN; BAGHEL, 2005; SUÁREZ-BARRAZA; DÁVILA, 2009).

While all of these work together with others not mentioned here, have made important contributions to the understanding of continuous improvement processes, it is still difficult to explain why the teachings of Deming, Juran, Ishikawa and other great teachers have not yet been able to be fully implemented in many organizations? And why it is so difficult to copy the successful systems (for example, the Toyota Production System)? when the concepts they applied are simple and easy to understand.

The objective of this work is to answer questions previously expressed. To do so, from the theory, we analyze the reality of continuous improvement processes in large organizations.

\section{THEORETICAL FRAMEWORK}

A review of the literature enabled us to determine the main factors to consider for the successful implementation of a continuous improvement process.

Table 1: Key Components of a Continuous Improvement Process.

Key Components Assessed

I. Formalization \& Structure

Il. Continuity / Duration

III. Deployment / Scope of Program

IV. Training

V. Management Commitment

VI. Program Coordination

VII. Methodology \& Tools

VIII. Performance Measurement

IX. Communication of Results, Recognition \& Incentives
Foundations

(ANAND et al., 2009; CHOO et al., 2007; FORMENTO et al., 2007; GRUTTER et al., 2002; TERZIOVSKI et al., 2000; WRUCK ; JENSEN, 1998)

(RAPP; EKLUND, 2002; SILLINCE et al., 1996; TERZIOVSKI et al., 2000)

(CHOO et al., 2007; WRUCK et al., 1998)

(BACDAYAN, 2001; RAPP et al., 2002; TERZIOVSKI et al., 2000; WOOD, 2003)

(ATTARAN, 2003; BASHEIN et al., 1994; BATEMAN; RICH, 2003; JORGENSEN et al., 2003; TERZIOVSKI et al., 2003)

(GRUTTER et al., 2002; RAP et al., 2002; SCHURING ; LUIJTEN, 2001; TERZIOVSKI et al., 2000)

(BATEMAN, 2005; FORMENTO et al., 2007; FORRESTER, 2000; GARVIN, 1993; HANDEL ; GITTLEMAN, 2004; PIL; MACDUFFIE, 1996; SPEAR; BOWEN, 1999; TERZIOVSKI et al., 2000)

(BESSANT; FRANCIS, 1999; DAS et al., 2000; DENNIS et al., 2003; EVANS; LINDSAY, 2008; FOSTER, 2004; HAMMER; STANTON, 1999)

(BUCH; SPANGLER, 1990; FAIRBANK; WILLIAMS, 2001; KERRIN; OLIVER, 2002; RAPP et al., 2002; LAWLER III, 1991; SILLINCE et al., 1996;) 
DOI: 10.14807/iimp.v4i2.76

The following table summarizes references from previous works that support the key components evaluated in our investigation.

\section{Formalization \& Structure}

In the absence of a formalized program, continuous improvement efforts are intermittent and depend on personal attitudes and circumstantial pressures. Formalization generates the field needed to create the support structure and establish the routines mentioned by Bessant et al. (2001) in their five evolutionary stages of process improvement. Without formalization and structure, it is impossible to move beyond the first level of evolution.

\section{Continuity / Duration}

A continuous improvement process-as the name implies-has no end to it. In contrast, improvement routines are expected to be integrated into the organization's daily activities and used to generate results in line with the firm's strategic objectives. The most prominent examples—such as the Toyota Production System-are stable and facilitate the spread of practices through the company (GARCÍA-SABATER et al., 2009).

The inability to maintain continuity creates a very negative impact on employees and has a limited duration (between one and four years) after going through three phases: introduction, spread, and decline. The reasons for this are diverse, but are generally related to static programs with no capacity for development (LAWLER III, 1991; SILLINCE et al., 1996). Sometimes there is a fourth phase in which the improvement effort is relaunched (RAPP et al., 2002). Regarding this same idea, Wu et al. (2006) argue that all activities (including improvements) have a life cycle which moves through introduction, growth, maturity, and decline. If a regenerative impulse is not achieved at the appropriate time, the program declines.

\section{Deployment / Scope of Program}

If continuous improvement is inadequately deployed and poorly coordinated, the process becomes less effective, even after achieving some initial results ( $\mathrm{CHOO}$ et al., 2007; WRUCK et al., 1998).

Continuity is important, but another critical factor is the way processes are deployed in order for improvement routines to reach all levels of the organization. The systemic approach (DEMING, 1993) requires that different processes are viewed 
DOI: 10.14807/iimp.v4i2.76

as part of a global system where the final result depends on the quality of the interactions between them. In this sense, it is unthinkable for continuous improvement to work without the integration of all sectors and processes.

\section{Training}

Modifying the classic structure of problem-solving using trial and error-based on individual experience-to the scientific method-using teams-requires specific training in methodologies and tools for analysis.

In addition to the need of large-scale training, it is reasonable to start with upper management and focus on the agents of change, which will generate a big impact on the process (SPEAR et al., 1999; SPEAR, 2004). Several studies highlight the importance of implementing training in basic tools and of moving toward new tools as soon as more complex problems make them necessary (BACDAYAN, 2001; RAPP et al., 2002; TERZIOVSKI et al., 2000; WOOD, 2003).

\section{Management Commitment}

Management commitment is needed so that participation and teamwork become part of the organizational culture (ATTARAN, 2003; BASHEIN; MARKUS; RILEY, 1994; JORGENSEN; BOER; GERTSEN, 2003; TERZIOVSKI; FITZPATRICK; O’NEILL, 2003).

It is not possible to develop a continuous improvement program without a strong commitment from top and senior management. Directors must agree to commit the required resources; align activities with strategic objectives; establish systems, procedures, and policies; and, most importantly, generate a culture of continuous improvement (GARCÍA-SABATER et al., 2009).

\section{Program Coordination}

The promotion of continuous improvement within the organizational routine requires actors which facilitate this within day-to-day activities. This role goes beyond specific team leaders and refers to the figure of one or more internal coordinators who support activities, facilitating access to resources and to providing methodological advice to team members (GARCÍA-SABATER et al., 2009).

\section{Methodology \& Tools}

The existence of a common scientific method is vital, and should include a predetermined routine of steps for the development of improvement projects 
DOI: $10.14807 / i i m p . v 4 i 2.76$

(FORRESTER, 2000; GARVIN, 1993; SPEAR et al., 1999). A formalized methodology enables a common working basis on which to developing changes (BATEMAN, 2005).

This systematic analysis process replaces the traditional trial-and-error approach to problem-solving.

A previous study of Australian firms by Terziovski et al. (2000) shows that these companies still prefer the seven basic tools over more advanced ones such as Failure Mode and Effect Analysis (FMEA) and Quality Function Deployment (QFD).

Another study conducted in Argentina demonstrates the ongoing use of the PDCA cycle and methods derived from it in a high percentage of improvement projects. The Six Sigma methodology is an alternative, using DMAIC cycle, and currently applied in lower percentage of cases. Both methods apply the 7 basic tools, which remain the most widely used (FORMENTO, 2008).

\section{Performance Measurement}

The development of continuous improvement capacities requires a process of monitoring and measuring results against the strategic objectives of the firm (BESSANT; FRANCIS, 1999).

Continuous improvement is based on continuous assessment techniques applied to systems, processes, and key results (DAS; HANDFIELD; CALANTONE; GHOSH, 2000; DENNIS; CARTE; KELLY, 2003; EVANS et al., 2008; FOSTER, 2004; HAMMER et al., 1999).

\section{Communication of Results, Recognition, and Incentives}

The experiences feedback within a continuous improvement program allows the building, analyzing, and facilitating of the exchange of knowledge between experts in problems solving (JABROUNI; KAMSU-FOGUEM; GENESTE; VAYSSE, 2011). When teams show their results for internal events, the knowledge they have developed is deployed beyond their own team members and applied to the whole organization. Additionally, in cases of external events, showing the successful results of a project operates as a motivational factor.

Significant contributions-measured in terms of their impact on results-are usually rewarded. These recognition programs can take different forms but always 
DOI: 10.14807/iimp.v4i2.76

attempt to reinforce and spread positive attitudes (BUCH et al., 1990; KERRIN et al., 2002; LAWLER III, 1991; RAPP et al., 2002; SILLINCE et al., 1996;).

\section{METHODOLOGY}

A qualitative and exploratory research design was undertaken in order to determine prominent components of key factors who explain the success of a continuous improvement program.

We analyzed, through an in-depth survey, a group of 30 large companies pertaining to the following activities: oil (5), foodstuffs (8), steel (5), automotive (4), chemicals (4) and services (4).

Companies considered for this study were chosen based on the following criteria:

- Large companies (more than \$ 25 million in annual sales).

- Leaders in their markets (considering their market share).

- Members of SAMECO (Argentine Society for Continuous Improvement) or FUNDECE (Business Foundation for Quality and Excellence).

- With a certified management system (ISO 9001, ISO 14001 or other specific norms of the activity.

The survey form was designed based on the theoretical framework for the project, which was made up of the classical literature on continuous improvement, placing emphasis on the key components described above.

The resulting survey included 67 questions, 20 of which were multiple choice. The survey was sent by e-mail to the continuous improvement coordinator of 52 companies. After telephone follow-up, response was obtained in 30 firms.

The rating of the results obtained, by the continuous improvement process, in each company was taken from the vision of the coordinator. The options were: very effective results, effective results, scarce results and ineffective results.

Survey results were processed statistically and stratified to display trends. The comments in open questions were discussed qualitatively to find signs of significant differences.

Finally we compared the answers and comments in companies with very effective results, by one side, with companies with scarce and ineffective results, by 
DOI: 10.14807/iimp.v4i2.76

the other side. Differences that emerged from this comparison enabled us to identify prominent components, inside the key factors, that seem to be critical, for achieving successful continuous improvement processes.

\section{OBSERVED RESULTS}

\subsection{Sample Profile}

Firms for this study correspond to the group called large companies, according to their billing levels and market share. Previous investigations in Argentina (FORMENTO; BRAIDOT; PITTALIGA, 2007), shows that companies of this size were the first to implement continuous improvement. Making a survey of the presentations made at the annual conference SAMECO (Argentina Society for Continuous Improvement), over 15 years, it appears that continuous improvement processes of these companies are among the most advanced in Argentina. The latter aspect is especially important to this study as it allows us to determine trends in the field.

Another feature of this group is that all companies have a certified management system. In addition, 18 companies have two or more certified standards, and 14 companies have an integrated management system.

Additionally, eight of these companies have won quality awards, including a National Quality Award of Argentina, the Iberoamerican Quality Award, the prize TPM in Japan, and the International Team Excellence Award of the American Society for Quality. These data confirm the level of the sample in terms of formal achievements in the field of quality systems, both locally and internationally.

\subsection{Findings on Key Factors}

\section{Formalization \& Structure}

At first glance, it would appear that there are few doubts, among firms, regarding the need for the existence of continuous improvement, given that 28 companies of the sample said that they have a formalized program. This contrasts strongly with a previous study of Argentinian SMEs (FORMENTO; ALTUBE; BRAIDOT; NICOLINI, 2006), which showed that there are improvement teams within only $36 \%$ of companies in the automotive sector, $17 \%$ in the steel sector, and around $10 \%$ in other sectors. 
DOI: 10.14807/iimp.v4i2.76

\section{Continuity / Duration}

The average age of the continuous improvement programs evaluated in this research is nine years. In 14 cases, programs were over 10 years old, and two firms had programs with more than 20 years.

This confirms that we are evaluating a set of pioneers in the field in Argentina. These kinds of programs first started to be developed in Argentina in the late 1980s.

Of all the companies that claim to have implemented a continuous improvement program, five of them said they had discontinued at some point. The same number of companies acknowledged that the continuous improvement program had not evolved within their organizations, which in principle could be considered a negative feature.

The main characteristics mentioned as evolving positively were: scope, results, number of projects, and people involved.

\section{Deployment / Scope of the Program}

The scope of the continuous improvement program in these companies shows logical and predictable results. In all cases with formal programs, the program reached the production areas. The rest of the areas reached by the program are, in order of importance: support areas, administrative areas, and commercial areas.

Table 2: Scope of the program (number of cases)

\begin{tabular}{|lc|}
\hline \multicolumn{1}{|c|}{ Areas } & Number of cases \\
\hline Production / Operations & 28 \\
\hline Support & 21 \\
\hline Administrative & 15 \\
\hline Commercial / Business & 12 \\
\hline
\end{tabular}

An important issue is the number of firms that reached support and administrative areas with continuous improvement programs. This is a good sign in terms of deployment of the program through the organization. It seems that continuous improvement is advancing from operational areas towards nonoperational ones.

\section{Training}

As was expected for firms of this size, 27 companies reported having a continuous improvement training program for their staff. 
DOI: 10.14807/iimp.v4i2.76

Sample analysis shows that in 18 firms, all staff is trained in continuous improvement.

Table 3: Recipients of continuous improvement's training program

\begin{tabular}{|lc|}
\hline \multicolumn{1}{c}{ Recipients } & Number of cases \\
\hline All staff & 18 \\
\hline Team members & 8 \\
\hline Team leaders & 3 \\
\hline Supervisors & 4 \\
\hline Facilitators & 3 \\
\hline Managers & 3 \\
\hline
\end{tabular}

Most companies (25 cases), apply internal training resources-that is, using their own staff to provide the training. Twelve of these companies combine this with external training. In contrast, very few companies (just two), work exclusively with external training.

The advantage and need for internal training had already been comprehensively stated by Shiba et al., (1995). Internal training gives strong signals of commitment mainly if managers participate.

All this seems to be in line with Ishikawa's famous phrase (1986) : "Quality begins with education and ends with education... to apply quality control we have to offer continuing education for everyone from the president to the workers". This sample suggests that things are moving in this direction.

\section{Management Commitment}

When we studied the level of involvement of firms' different hierarchical levels within quality management systems, we found that although the involvement rate of top management appears higher than the middle and operational levels, it was noteworthy that over $50 \%$ of managers did not have high involvement levels and that $17 \%$ had low involvement levels. This could explain the involvement rates at middle and operational levels, because managers' attitudes spread rapidly to the rest of the organization.

In this respect, interpreting the words of Meegan and Taylor (1997), we believe that "strong motivation" should mean "high involvement". This is not observed in table 4 , where - in contrast-over $50 \%$ of staff shows middle or low involvement. 
Table 4: Management Involvement (number of cases)

\begin{tabular}{|lcccc|}
\hline Hierarchical Level & High & Medium & Low & No answer \\
\hline Senior management & 14 & 9 & 5 & 2 \\
\hline Middle management & 14 & 12 & 2 & 2 \\
\hline Operators & 9 & 15 & 4 & 2 \\
\hline
\end{tabular}

\section{Program Coordination}

These programs are not always coordinated by the same management area.

This highlights the emergence of special sectors that are specifically dedicated to tasks related to quality management and continuous improvement. These new organizational sectors, which differ from the classical structures, show the evolution of the importance assigned to these programs. High rated's human resources are allocated to manage and facilitate the quality system and continuous improvement program.

There is no uniform name for these areas, so each company uses their own term to refer to them. However, the important issue here is having a small and highly qualified group of human resources devoted entirely to managing improvement tasks.

According to data collected (27 answers), this positive outcome seems to be becoming a trend.

Table 5: Program Coordination.

\begin{tabular}{|lc|}
\hline Sector & Number of cases \\
\hline Special areas & 14 \\
\hline Quality & 7 \\
\hline Production line & 4 \\
\hline Other & 2 \\
\hline Total & 27 \\
\hline
\end{tabular}

Some of the names identified for special areas are: Total Quality Management, Continuous Improvement, Technology Management, Operational Excellence, Six Sigma, etc.

We also analyzed the make-up of the group and the different roles used to coordinate continuous improvement projects.

In companies with formalized programs we found that, in 24 of them, there are different roles within teams. 
DOI: $10.14807 / i i m p . v 4 i 2.76$

The vast majority of companies in the sample have assigned the roles of leader (23 cases), and facilitator (20 cases). It is understood that these two roles are key to promoting and managing teams that carry out projects and continuous improvement actions.

If we analyze companies which use different roles in teams, within their formalized programs, we find that there are no leaders just in one case and there are no facilitators just in four cases. In many cases, facilitators are part of special areas (see table 5), that coordinate the improvement program.

An equally interesting fact is that in $50 \%$ of cases, in which there are different roles, the figure of sponsor or mentor is used. These configurations tend to provide greater sustainability to the performance of continuous improvement teams. Experience indicates that in the absence of these roles, work can become more dependent on individual tenacity and less effective.

Other roles, such as secretary, have a very low presence in the team structures evaluated in this sample.

Table 6: Existence of different roles within teams.

\begin{tabular}{|lc|}
\hline \multicolumn{1}{|c|}{ Roles } & Number of cases \\
\hline Leader & 23 \\
\hline Facilitator & 20 \\
\hline Sponsor/mentor & 12 \\
\hline Secretary & 4 \\
\hline Others & 6 \\
\hline
\end{tabular}

We then analyzed the situation in more depth by exploring who is assigned to perform the different roles in improvement teams within the formal structure.

The Figure 1 shows the percentage of cases where top management, middle management, supervisors, employees, and the improvement committee take on the different roles.

We can conclude that internal facilitators and leaders are mostly middle managers and supervisors.

The team members are mainly employees, supervisors and middle managers.

As expected, approval of the action plans is in charge of senior and middle management and improvement committee. 
DOI: $10.14807 / i i m p . v 4 i 2.76$

Finally, launching and closing projects lies mainly in the hands of senior management and middle management.

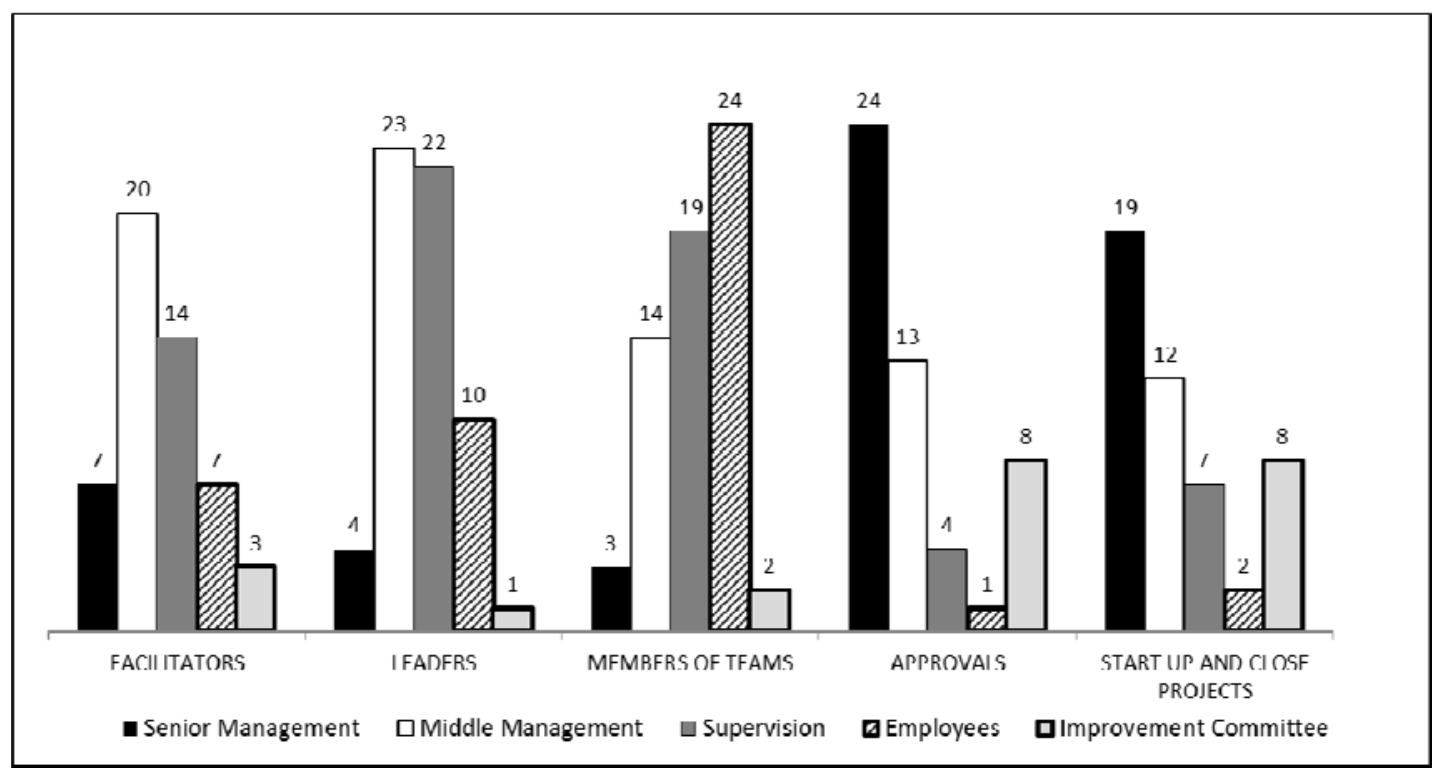

Figure 1.Roles played by different hierarchical levels (number of cases).

\section{Methodology \& Tools}

All the 28 cases with formalized programs stated that they use a methodology and tools for problem-solving.

It is not possible to identify in detail tools and methods applied, due to the vast number and the different ways that companies refer to them. Nevertheless, table 7 shows the methods and tools more mentioned by respondents when talking on methodology.

Table 7: Tools and methods used.

\begin{tabular}{|lc|}
\hline \multicolumn{1}{|c|}{ Name } & Number of cases \\
\hline B Basic Tools & 24 \\
\hline SS & 17 \\
\hline Kaizen & 13 \\
\hline 7 New Tools & 12 \\
\hline Benchmarking & 12 \\
\hline FMEA & 10 \\
\hline TPM & 9 \\
\hline 8 Steps Method & 9 \\
\hline Six Sigma & 7 \\
\hline SQC & 5 \\
\hline QFD & 3 \\
\hline
\end{tabular}


DOI: 10.14807/iimp.v4i2.76

As we can observe most (80\%) still use basic tools, followed by $5 \mathrm{~S}, 7$ new tools, benchmarking, and FMEA, and others that were mentioned less frequently. This result is consistent with previous research on the subject, which shows the same tendencies (FORMENTO, 2008). It seems evident, in this sense, that basic methods are very accessible, can be used by all employees after short training courses, and are appropriate for a high percentage of chronic problems in companies. New trends, such as Six Sigma, are observed in seven of the cases.

While the table shows methodologies being combined with tools and toolkits, we can conclude that basic tools continue to be massively used.

\section{Performance Measurement}

Improvement teams address a wide range of issues which has been classified into the following areas: Quality/Defects; Cost/Benefits; Standard deviations; Environment; Security; Change/Innovation; and Others.

Table 8: Issues addressed by continuous improvement projects.

\begin{tabular}{|lc|}
\hline \multicolumn{1}{|c|}{ Issues } & Number of cases \\
\hline Quality / defects & 25 \\
\hline Costs /benefits & 23 \\
\hline Deviation from the standard & 23 \\
\hline Security & 22 \\
\hline Changes / innovations & 22 \\
\hline Environment & 20 \\
\hline Others & 9 \\
\hline
\end{tabular}

It must be remembered that these rankings are tentative, since most improvement projects make an impact on several areas simultaneously.

When searching how these topics emerged as improvement projects, we found that the origins detected are very varied (these results are shown in table 9). Deviations from standards and managers' proposals stand out as the two largest groups. This seems to show a relationship between improvement programs and the company's strategy, although this is not enough to assure it.

A second group emerges which consists of customer complaints and staff suggestions. Although customer complaints are very important, this group should never represent a majority because, were that the case, it would reveal great 
problems in dealing with customers and therefore indicates a company that works very "reactively" and is permanently in a risk zone.

The staff suggestions are a category, possibly of minor impact, but one that is nonetheless important to ensuring employee involvement and sense of pertaining.

Table 9: Project origins.

\begin{tabular}{|ll|}
\hline \multicolumn{1}{|c|}{ Origin } & Number of cases \\
\hline Deviation from standards & 24 \\
\hline Managers' proposals & 23 \\
\hline Customer complaints & 17 \\
\hline Staff suggestions & 16 \\
\hline Surveys & 9 \\
\hline Others & 6 \\
\hline
\end{tabular}

The impact of the implementation of continuous improvement program, in each company, is a critical data to understand which are the key factors in this process. As mentioned in methodology, we took this result from the internal coordinator's point of view.

The following table shows that a relatively small number of companies consider their program to be "very effective"; just eight firms. Nevertheless, nobody consider the program as ineffective, but nine companies considered the results are scarce.

Table 10: Results of continuous improvement programs.

\begin{tabular}{|c|c|}
\hline Result & Number of cases \\
\hline Effective & 13 \\
\hline Very effective & 8 \\
\hline Scarce & 9 \\
\hline Ineffective & 0 \\
\hline Total & 30 \\
\hline
\end{tabular}

With respect to the information available for decision-making at high organizational levels, only 12 companies have expressed that they have statistics on improvement projects, both completed or in development.

On the other hand, in just 16 cases, costs of poor-quality have been calculated. 
DOI: 10.14807/iimp.v4i2.76

Program statistics are essential to generating information that increases the body of knowledge and learning so that companies can make good decisions when they need it.

\section{Communication of Results, Recognition \& Incentives}

Our question about the existence of a recognition system elicited a positive result in 21 of the firms being investigated.

When asked about the recipients of this recognition, it appears that the trend is to include all participants and all team members. Only five organizations mentioned that they give recognition exclusively to operations personnel, and three applies it only to the best teams.

The type of recognition is mainly non-cash, and is based on entertainment, gifts, and internal and external events.

Some of the companies that reported not having a formal recognition program had, nonetheless developed other forms of recognition. As such, only 7 firms of the sample have no kind of recognition for the staff.

Table 11: Forms of Recognition.

\begin{tabular}{|lc|}
\hline \multicolumn{1}{|c|}{ Forms } & Number of cases \\
\hline Gifts & 19 \\
\hline Internal events & 14 \\
\hline External events & 13 \\
\hline Dinners & 10 \\
\hline Money & 6 \\
\hline
\end{tabular}

Several of the alternatives for recognition, shown in table 11, are used in combination.

Although only 14 companies mentioned internal events as a form of recognition, 18 firms, say there are presentations of improvement teams in such events. In 16 cases, senior management takes part of internal events. In contrast, only nine organizations included all staff and only three of them include people outside the company.

We would like to emphasize several aspects. One is that the need for recognition is generally accepted. On the other hand, the internal events, as a form of 
DOI: 10.14807/iimp.v4i2.76

recognition, are only used in less than $50 \%$ of the sample, even in cases where managers' involvement is high.

Finally there is little external benchmarking, since less than $50 \%$ of sample participate in external events and people of other companies are only invited to internal team presentations in just three cases.

\section{DISCUSSION OF FINDINGS}

This section contains a comparative analysis of data.

We confront data from companies with very effective results with data from companies with scarce results. The group of companies that qualifies only as effective is not part of this comparison, to seek a better contrast between the extremes.

The above remark is based on an understanding that the label "effective" is a necessary but insufficient condition. In other words, if this type of initiative does not generate enthusiasm, it will have limited consistency and its permanence will be in doubt. It should be kept in mind that continuous improvement generates a permanent stress (in terms of resource commitment) with companies' daily routines.

Starting with the elements that seem to have no influence on the effectiveness of the continuous improvement process, table 12 shows the number of companies, out of the total in the group, who certify standards, apply to models of excellence and have training programs on continuous improvement.

Table 12: Number of companies in each category.

\begin{tabular}{|c|c|c|}
\hline Formal aspects & $\begin{array}{c}\text { Process with } \\
\text { very effective } \\
\text { results } \\
\mathbf{8} \text { firms }\end{array}$ & $\begin{array}{c}\text { Process } \\
\text { with scarce } \\
\text { results } \\
\mathbf{9} \text { firms }\end{array}$ \\
\hline ISO 9001 Certification & 5 & 8 \\
\hline ISO 14001 Certification & 6 & 5 \\
\hline Application of Excellence Models & 5 & 4 \\
\hline Training program on continuous improvement & 7 & 8 \\
\hline
\end{tabular}

No relationship seems to have between ISO 9001 certification and the results of continuous improvement process. The group of companies that achieved very effective results (almost $27 \%$ of the sample) includes companies without ISO 9001 certification. 
Likewise, there is no evidence that models of excellence and quality awards ensure an adequate continuous improvement process. When we analyze the seven cases, in the whole sample, that have won quality awards, it emerges that only three of them have continuous improvement programs very effective, two qualify just as merely effectives, one as scarce results, while the remaining do not have a formalized program.

Additionally, the existence of a continuous improvement's training program does not seem to be an element that produce a difference on results.

From the above we conclude that the systems and strategies mentioned (certification and models), and the training programs are desirable but do not ensure a very effective continuous improvement process.

We now analyze the main components of the key factors to look for significant differences. Table 13 shows the deployment of the nine factors and the number of firms in each group that complies them.

Table 13: Differences in key factors.

\begin{tabular}{|c|c|c|c|}
\hline Key Factors & Prominent Components & $\begin{array}{c}\text { Process with } \\
\text { very effective } \\
\text { results } \\
8 \text { firms }\end{array}$ & $\begin{array}{l}\text { Process } \\
\text { with scarce } \\
\text { results } \\
9 \text { firms }\end{array}$ \\
\hline \multirow{2}{*}{ Formalization \& Structure } & Existence of formal program & 8 & 7 \\
\hline & Existence of Continuous Improvement teams & 8 & 5 \\
\hline \multirow{3}{*}{ Continuity / Duration } & Never was discontinued & 8 & 4 \\
\hline & It evolved over time & 8 & 3 \\
\hline & Age of the program (average) & 9,1 years & 9,7 years \\
\hline \multirow{2}{*}{$\begin{array}{l}\text { Deployment / Scope of the } \\
\text { program }\end{array}$} & Projects also apply on support areas & 8 & 4 \\
\hline & Percentage of employees involved (average) & $53 \%$ & $17 \%$ \\
\hline \multirow{2}{*}{ Training } & Training program on continuous improvement & 7 & 8 \\
\hline & Training for all staff & 4 & 7 \\
\hline \multirow{4}{*}{ Management Commitment } & Managers identify topics for improvements & 8 & 4 \\
\hline & Managers approve topics for improvement & 8 & 6 \\
\hline & Managers open and close projects & 8 & 3 \\
\hline & Senior management participate in internal events & 7 & 3 \\
\hline \multirow{2}{*}{ Program Coordination } & Middle managers facilitate teams & 8 & 5 \\
\hline & Different roles to coordinate teams & 8 & 4 \\
\hline \multirow{3}{*}{ Methodology \& Tools } & There are an official method for teamwork & 8 & 4 \\
\hline & Interdisciplinary teams & 8 & 5 \\
\hline & Use of basic tools & 8 & 6 \\
\hline \multirow{2}{*}{ Performance Measurement } & Measurement of avoided cost & 8 & 2 \\
\hline & Measurement of participation & 8 & 4 \\
\hline \multirow{2}{*}{$\begin{array}{l}\text { Communication of Results, } \\
\text { Recognition \& Incentives }\end{array}$} & Existence of recognition program & 8 & 4 \\
\hline & Teams' presentation in internal events & 6 & 4 \\
\hline
\end{tabular}


DOI: $10.14807 / i i m p . v 4 i 2.76$

The table shows another component that does not impact the difference in results: the duration of the process. This means that a continuous improvement program can exist for a long time and still have poor results.

Looking for components that can explain the differences we observed a number of items present in $100 \%$ of companies with very effective results. These items appear only in some of the companies with scarce results.

However, all components are present in some company of the second group. Therefore, a question that arises is: any of these companies meets all the key factors?.

The answer is in Table 14, which shows the nine cases of firms with scarce results. This table shows only the components that are present in $100 \%$ of companies with very effective results. As you can see, none of these companies meets all the components.

Table 14: Components in processes with scarce results.

\begin{tabular}{|c|c|c|c|c|c|c|c|c|c|}
\hline Prominent Components & \multicolumn{7}{|c|}{ Process with scarce results (Cases) } \\
\hline & $\mathbf{1}$ & $\mathbf{2}$ & $\mathbf{3}$ & $\mathbf{4}$ & $\mathbf{5}$ & $\mathbf{6}$ & $\mathbf{7}$ & $\mathbf{8}$ & $\mathbf{9}$ \\
\hline Existence of formal program & $\mathrm{X}$ & $\mathrm{X}$ & $\mathrm{X}$ & $\mathrm{X}$ & $\mathrm{X}$ & & & $\mathrm{X}$ & $\mathrm{X}$ \\
\hline Existence of Continuous Improvement teams & $\mathrm{X}$ & $\mathrm{X}$ & & $\mathrm{X}$ & & & $\mathrm{X}$ & $\mathrm{X}$ & \\
\hline Never was discontinued & $\mathrm{X}$ & $\mathrm{X}$ & $\mathrm{X}$ & $\mathrm{X}$ & & & & & \\
\hline It evolved over time & $\mathrm{X}$ & $\mathrm{X}$ & $\mathrm{X}$ & & & & & & \\
\hline Projects also apply on support areas & & $\mathrm{X}$ & $\mathrm{X}$ & & $\mathrm{X}$ & & & $\mathrm{X}$ & \\
\hline Percentage of employees involved (average) & $5 \%$ & & $\mathbf{2 \%}$ & $30 \%$ & $30 \%$ & & & & \\
\hline Managers identify topics for improvements & & $\mathrm{X}$ & $\mathrm{X}$ & & & & $\mathrm{X}$ & $\mathrm{X}$ & \\
\hline Managers approve topics for improvement & $\mathrm{X}$ & $\mathrm{X}$ & $\mathrm{X}$ & & $\mathrm{X}$ & & $\mathrm{X}$ & $\mathrm{X}$ & \\
\hline Managers open and close projects & & $\mathrm{X}$ & $\mathrm{X}$ & & & & $\mathrm{X}$ & & \\
\hline Middle managers facilitate teams & $\mathrm{X}$ & $\mathrm{X}$ & $\mathrm{X}$ & & $\mathrm{X}$ & & & $\mathrm{X}$ & \\
\hline Different roles to coordinate teams & $\mathrm{X}$ & $\mathrm{X}$ & $\mathrm{X}$ & & $\mathrm{X}$ & & & & \\
\hline There are an official method for teamwork & $\mathrm{X}$ & $\mathrm{X}$ & & & $\mathrm{X}$ & & $\mathrm{X}$ & & \\
\hline Interdisciplinary teams & $\mathrm{X}$ & $\mathrm{X}$ & & $\mathrm{X}$ & $\mathrm{X}$ & & & $\mathrm{X}$ & \\
\hline Use of basic tools & $\mathrm{X}$ & & $\mathrm{X}$ & $\mathrm{X}$ & $\mathrm{X}$ & & $\mathrm{X}$ & $\mathrm{X}$ & \\
\hline Measurement of avoided cost & & $\mathrm{X}$ & & & $\mathrm{X}$ & & & & \\
\hline Measurement of participation & $\mathrm{X}$ & & $\mathrm{X}$ & $\mathrm{X}$ & $\mathrm{X}$ & & & & \\
\hline Existence of recognition program & $\mathrm{X}$ & $\mathrm{X}$ & & & $\mathrm{X}$ & & & $\mathrm{X}$ & \\
\hline
\end{tabular}

The cases are diverse. For example: in case 1, which meets most of the components, the improvement projects do not reach support areas, the percentage of employee participation is low, managers are not involved in the selection of topics and in the opening and closing of projects and finally, they do not measure avoided cost.

The case 2, which seems to be the most comprehensive in this group, do not use basic tools - when statistics say they are the most effective and used in 
DOI: 10.14807/iimp.v4i2.76

continuous improvement projects - and do not recorded or measured participation. The latter suggests that may be low.

Completely different from Case 2 is the case 6 , where none of evaluated components are present. Interestingly, this company is certified ISO 9001, ISO 14001 and won the national quality award of Argentina.

In summary, all these cases have shortcomings with respect to very effective processes. Cases 3 and 4 , do not have recognition program and a standardized method for teamwork, among other difficulties.

In case 5, we see: discontinuity, lack of evolution and poor managerial involvement.

Finally in cases 7 to 9, appear as common shortcomings lack of: continuity, evolution, measurements and roles in teams.

\section{CONCLUSIONS}

The observations above enable us to draw some preliminary conclusions, which must be confirmed or refuted in future research.

On the basis of the findings discussed in the previous sections, we can infer that approximately one in three large companies have a continuous improvement program with very effective results. This means that they have developed high standards and are thus benchmarks for other companies, even though they still need to develop further themselves.

It seems evident from previous comparison that the prominent components identified, into the nine key factors, make a difference in terms of the effectiveness of results. Table 14 shows the seventeen mentioned components.

Companies with continuous improvement processes very effective, in $100 \%$ of cases, meet all these components. In contrast, none of the companies with poor results meets all prominent components.

From Table 13 it appears that the most remarkable differences are observed in:

- Measurement (avoided cost and participation)

- Percentage of employees involved

- Management participation 
DOI: 10.14807/iimp.v4i2.76

- Recognition

- Projects applying to support areas

- Continuity

- Different roles in teams

- Standard method for teamwork

To summarize, we recommend establishing lines of work which take into account the nine key factors and, specially, the seventeen prominent components mentioned in the previous paragraph, since they seem to explain the difference between very effective and ineffective processes.

It is important to clarify that the presence of a key factor or a prominent component in a company that did not experience very effective results does not contradict our findings, since the key factors and their components operate together, as a system. Therefore the appearance of one of these factors alone does not guarantee results.

The latter may apply to training, which has not been demonstrated to be a differentiating factor. Training is a key factor (Table 13), of continuous improvement, but it is as a necessary but insufficient condition. In other words, most of the firms in the group with scarce results have a training program for continuous improvement, which is fine, but the process lacks other key components which prevent them from reaping the benefits of training.

While each organization must develop its own continuous improvement strategy, a working plan oriented to these findings may increase the success possibilities.

We understand this research contributes to the study of continuous improvement processes in Argentina and could be of interest to develop more effective strategies on the matter.

However, further research must confirm these findings and move forward on the analysis of intangible factors, like: internal communications, internal climate, culture, self reflexion, consensus, etc. Those factors could play an important role in building a highly effective continuous improvement program in conjunction with the ones here researched. 
DOI: $10.14807 / i i m p . v 4 i 2.76$

\section{ACKNOWLEDGEMENT}

The authors want to acknowledge the support provided by SAMECO (Argentine society for continuous improvement), opening the access to a great number of cases for study and the Industry Institute at the National University of General Sarmiento where we developed our work during the two years of research.

\section{REFERENCES}

ALBORS GARRIGOS, J.; HERVAS OLIVER J. L.; SEGARRA OÑA, M. (2009) Análisis de las prácticas de mejora continua en España. Economía Industrial, n. 373, p. 185-195.

ANAND, G.; WARD, P.; TATIKONDA, M.; SHILLING, D. (2009) Dynamic capabilities through continuous improvement infrastructure. Journal of Operations

Management, v. 27, n. 6, p. 444-461.

ATTARAN, M. (2003) Information technology and business-process redesign.

Business Process Management Journal, v. 9, n. 4, p. 440-459.

BACDAYAN, P. (2001) Quality improvement teams that stall due to poor project selection: an exploration of contributing factors. Total Quality Management, v. 12, n. 5, p. 589-598.

BATEMAN, N. (2005) Sustainability: the elusive element of process improvement. International Journal of Operations \& Production Management, v. 25, n. 3, p. 261-276.

BATEMAN, N.; RICH N. (2003) Companies' perceptions of inhibitors and enablers for process improvement activities. International Journal of Operations \& Production Management, v. 23, n. 2, p. 185-199.

BASHEIN, B.; MARKUS, L.; RILEY, P. (1994) Preconditions for BPR success and how to prevent failures. Information System Management, v. 11, n. 2, p. 7-13.

BESSANT, J.; CAFFYN, S.; GALLAGHER, M. (2001) An evolutionary model of continuous improvement behaviour. Technovation, v. 21, n. 2, p. 67-77.

BESSANT, J.; FRANCIS, D. (1999) Developing strategic continuous improvement capability. International Journal of Operations \& Production Management, v. 19, n. 11, p. 1106-1119.

BHUIYAN, N.; BAGHEL, A. (2005) An overview of continuous improvement: from the past to the Present. Management Decision, v. 43, n. 5, p. 761-771.

BUCH, K.; SPANGLER, R. (1990) The effects of quality circles on performance and promotions. Human Relations, v. 43, n. 6, p. 573-582.

BUCKLER, B. (1996) A learning process model to achieve continuous improvement and innovation. The Learning Organization. V. 3, n. 3, p. 31-39.

CHOI, T. (1995) Conceptualizing continuous improvement: Implications for organizational change. Omega, v. 23, n. 6, p. 607-624.

CHOO, A.; LINDERMAN, K.; SCHROEDER, R. (2007) Method and context perspectives on learning and knowledge creation in quality management. Journal of Operations Management, v. 25, n. 4, p. 918-931. 
DAS, A.; HANDFIELD, R.; CALANTONE, R.; GHOSH, S. (2000) A contingent view of quality management-the impact of international competition on quality. Decision Sciences, v. 31, n. 3, p. 649-690.

DAVISON, S.; GORDON, J. L.; ROBINSON, J. A. (2005) Studying continuous improvement from a knowledge perspective. Knowledge-Based Systems, v. 18, n. 4-5, p. 197-206.

DEMING, W. E. (1993) The new economics. Cambridge: MIT Center for advanced engineering study.

DENNIS, A.; CARTE, T.; KELLY, C. (2003) Breaking the rules: Success and failure in group-ware-supported BRP. Decision Support Systems, v. 36, n. 1, p. 31-48.

EVANS, J. R.; LINDSAY, W. R. (2008) Managing for quality and performance excellence. SW: Thomson.

FAIRBANK, J.; WILLIAMS, S. (2001) Motivating creativity and enhancing innovation through employee suggestion system technology. Creativity \& Innovation Management, v. 10, n. 2, p. 68.

Formento, H. (2008). Tendencias en el uso de herramientas para mejora e innovación. Inaugural conference 13th congress of SAMECO-Argentine Society for Continuous Improvement. Buenos Aires: Oct., 2008. Available: http://mejoracontinuatotal.blogspot.com/2012/03/estadisticas-sobre-el-uso-de.html

FORMENTO, H.; ALTUBE, L.; BRAIDOT, N.; NICOLINI, J. (2006) Estudio sobre los resultados y la correlación de variables de un modelo diagnóstico específico para PyMEs aplicado a distintas áreas de actividad industrial. LITTEC IFI 2Research's laboratory on technology, work, enterprise and competitiveness (Research paper 2). Available:

http://www.littec.ungs.edu.ar/pdfespa\%F1ol/IFI\%2002-2006\%20Formento-BraidotNicollini-Altube.pdf

FORMENTO, H.; BRAIDOT, N.; PITTALUGA, J. (2007) El proceso de mejora continua en PyMEs Argentinas: Investigaciones y modelos posibles. Buenos Aires: UNGS.

FORMENTO, H.; BRAIDOT, N.; FARDELLI, C.; CUSOLITO, F. (2007) Equipos de mejora contínua: Reglas para trabajo en equipo y resolución de problemas. Buenos Aires: UNGS.

FORRESTER, R. (2000) Capturing learning and applying knowledge: an investigation of the use of innovation teams in Japanese and American automotive firms. Journal of Business Research, v. 47, n. 1, p. 35-45.

FOSTER, S. T. (2004) Managing Quality: An Integrative Approach. NY: Prentice Hall. GARCÍA-SABATER, J.; MARIN-GARCIA, J. (2009) Facilitadores y barreras para la sostenibilidad de la mejora continua: Un estudio cualitativo en proveedores del automóvil de la Comunidad Valenciana. Intangible Capital, v. 5, n. 2, 183-209.

GARVIN, D. A. (1993) Building a learning organization. Harvard Business Review, v. 71, n. 4, p. 78-91.

GRUTTER, A.; FIELD, J.; FAULL, N. (2002) Work team performance over time: three case studies of South African manufacturers. Journal of Operations Management, v. 20 , n. 5 , p. $641-657$. 
HAMMER, M.; STANTON, S. (1999) How process enterprise really work. Harvard Business Review, v. 77, n. 6, p. 108-119.

HANDEL, M.; GITTLEMAN, M. (2004) Is there a wage payoff to innovative work practices?. Industrial Relations, v. 43, n. 1, p. 67-97.

IMAI, M. (1986) Kaizen: the key to Japan's competitive success. NY: Random House.

ISHIKAWA, K. (1986) ¿Qué es el control total de calidad?: la modalidad Japonesa. Bogota: Norma.

JABROUNI, H.; KAMSU-FOGUEM, B.; GENESTE, L.; VAYSSE, C. (2011) Continuous improvement through knowledge-guided analysis in experience feedback. Engineering Applications of Artificial Intelligence, v. 24, n. 8, p. 14191431.

JORGENSEN, F.; BOER, H.; GERTSEN, F. (2003) Jump-starting continuous improvement through self-assessment. International Journal of Operations \& Production Management, v. 23, n. 10, p. 1260-1278.

JUNG, J. Y.; WANG, Y. J. (2006) Relationship between total quality management (TQM) and continuous improvement of international project management (CIIPM). Technovation, v. 26, n. 5-6, p.716-722.

KERRIN, M.; OLIVER, N. (2002) Collective and individual improvement activities: the role of reward systems. Personnel review, v. 31, m. 3, p. 320-337.

LAWLER III, E. E. (1991) High involvement management. San Francisco: JosseyBass.

MARIN GARCIA, J. A.; PARDO DEL VAL, M. BONAVIA MARTIN, T. (2008) La mejora continua como innovación incremental. El caso de una empresa industrial española. Economía Industrial, n. 368, p. 155-167.

MEEGAN, S. T.; TAYLOR, W. A. (1997) Factors influencing a successful transition from ISO 9000 to TQM: the influence of understanding and motivation. International Journal of Quality \& Reliability Management, v. 14, n. 2, p. 100-117.

MESQUITA, M.; ALLIPRANDINI, D. H. (2003) Competências essenciais para melhoria contínua da produção: estudo de caso em empresas da indústria de autopeças. Gestão \& Produção, v.10, n.1, p.17-33.

MURRAY, P.; CHAPMAN, R. (2003) From continuous improvement to organizational learning. The Learning Organization, v. 10, n. 5, p. 272-282.

PIL, F.; MACDUFFIE, J. (1996) The adoption of high-involvement work practices.

Industrial Relations, V. 35, N. 3, P. 423-455.

RAPP, C.; EKLUND, J. (2002) Sustainable development of improvement activities: the long-term operation of a suggestion scheme in a Swedish company. Total Quality Management, v. 13, n. 7, p. 945-969.

SAVOLAINEN, T.; HAIKONEN, A. (2007) Dynamics of organizational learning and continuous improvement in six sigma implementation. The TQM Magazine, v. 19, $\mathrm{n}$. 1, p. 6-17. 
SCHURING, R.; LUIJTEN, H. (2001) Reinventing suggestion systems for continuous improvement. International Journal of Technology Management, v. 22, n. 4, p. 359-372.

SCOTT, S. C.; WILCOCK, E. A.; KANETKAR, V. (2009) A survey of structured continuous improvement programs in the Canadian food sector. Food Control, v. 20, n. 3, p. 209-217.

SHIBA, S.; GRAHAM, A.; WALDEN, D. (1995) TQM desarrollos avanzados. Madrid: Productivity Press.

SILLINCE, J.; SYKES, G.; SINGH, D. (1996) Implementation, problems, success and longevity of quality circle programs: a study of $95 \mathrm{UK}$ organizations. International Journal of Operations and Production Management, v. 16, n. 4, p. 88-111.

SPEAR, S.; BOWEN, H. K. (1999) Decoding the DNA of the Toyota Production System. Harvard Business Review, V. 77, N. 5, P. 96-106.

SPEAR, S. J. (2004) Learning to lead at Toyota. Harvard Business Review, v. 82, n. 5, p. 78-91.

SUAREZ-BARRAZA, F. M.; MIGUEL-DAVILA, J. A. (2008) Encontrando al "Kaizen": un análisis teórico de la "mejora continua". Pecunia, n. 7, p. 285-311.

TERZIOVSKI, M.; FITZPATRICK, P.; O'NEILL, P. (2003) Successful predictors of business process reengineering (BPR) in financial services. International Journal of Production Economics, v. 84, n. 1, p. 35-51.

TERZIOVSKI, M.; SOHAL, A. S. (2000) The adoption of continuous improvement and innovation strategies in Australian manufacturing firms. Technovation, v. 20, n. 10, p. $539-550$.

WOOD, A. (2003) Managing employees' ideas: from where do ideas come?. Journal for Quality \& Participation, v. 26, n. 2, p. 22.

WRUCK, K.; JENSEN, M. (1998) The two key principles behind effective TQM program. European Financial Management, v. 4, n. 3, p. 401-423.

WU, C.; CHEN, C. (2006) An integrated structural model toward successful continuous improvement activity. Technovation, v. 26, n. 5-6, p. 697-707. 